\title{
Ownership Concentration, Financial Leverage and Inefficient Investment-evidence from Chinese A-share Market
}

\author{
Zhang Xinyuan ${ }^{1}$, Bao Nan ${ }^{2}$, Zhao Yufei $^{3}$ \\ ${ }^{1}$ Finance Department of International Business School, Jinan University, Zhuhai, China \\ ${ }^{2}$ Electrical and Information College, Jinan University, Zhuhai, China \\ ${ }^{3}$ Accounting Department of Management School, Jinan University, Guangzhou, China \\ Correspondence: Zhang Xinyuan, Finance Department of International Business School, Jinan University, Qianshan \\ Road 206\#, Zhuhai City, Post No 519070, Guangdong Province, China.
}

Received: June 11, 2016

Accepted: July 12, 2017

Available online: July 13, 2017

doi:10.11114/afa.v3i2.2478

URL: https://doi.org/10.11114/afa.v3i2.2478

\begin{abstract}
This paper analyzes the data from Chinese A-share market during 2 years from 2014 to 2015. Basing on 2297 listed firms, we use theoretical analysis and empirical analysis to explore and validate the relationship between ownership concentration, financial leverage and the company's inefficient investment behavior. The result shows that in Chinese A-share market, financial leverage can effectively inhibit the company's inefficient investment behavior; the concentration of equity will effectively inhibit the company's inefficient investment behavior.
\end{abstract}

Keywords: ownership concentration; financial leverage; inefficient investment

\section{Introduction}

Financing and investment are two major financial activities for firms. Financing correlates to the financial leverage, determining the financial structure of firms. Investment decision is not only the allocation of firm's resources, but also the power of economic growth. The level of efficiency directly related to the success of the company.

Inefficient investment can be divided into two categories: over-investment and under-investment. When firms invest the funds in the project that net present value less than zero, it is called over-investment. When firms have idle funds but give up the project that net present value exceed zero, it is called under-investment. How to effectively curb inefficient investment is still a topic of great concern in academic and practice.

Ownership concentration and financial leverage are cited as the most two factors in corporate topic. But they have few correlate to inefficient investment. This paper tends to expand the influence factor about inefficient investment. Besides, verifying the effect that ownership concentration and financial leverage impact on inefficient investment in Chinese A-share market.

\subsection{Literature Overview of International Research}

Jensen (1986) have put forward that the separation between ownership and the right to operate would lead to excessive investment of corporations. When enterprises possess idle cash flow, most managers would put superfluous capital into the program whose NVP is zero or even less than zero in order to gain private interests.

Stulz (1990) has thought that governors would gain extra interests by investing as much as possible. Debt financing could cut back resources controlled by managers and have inhibitory effect on their excessive investment motivation to a large extent.

Myers (1997) has proposed that corporations only could accept those projects in which the total of debt interest and original cost of investment is more than the present value of net cash flow when the company is in debt and give up ones in the opposite position. Due to NPV is above the zero, investment may be not enough. In conclusion, Myers has prospected that financial leverage has negative correlation with investment expenditure.

Lang (1996) has tested two theories that are about excessive investment and insufficient investment respectively. Then he has taken the data of American industrial listed companies as a sample and imposed controls on opportunities of growth in a company on this theoretical basis. It has been found that the negative correlation between investment 
expenditure and financial leverage only suited firms in lack of potential growth, not those with a rapid development.

Claessens (2000) has analyzed listed companies in 9 various countries and districts in East Asia and put forward that controlling shareholders would usually have cross-holdings by adopting pyramid ownership structure in order to achieve the separation between the right of handling cash flow and operating. When making investment decisions, they would carry out related party transactions and asset repurchase to distort enterprise investment behavior and they also use their right of controlling to seek private benefits so that goals of companies and shareholders' interests would be deviated and interests of small shareholders would be harmed. Finally, all these would result in kinds of inefficient investment decisions of firms.

Aivazian (2005) has carried out empirical analysis with financial data of listed companies in Canada and found that financial leverage has negative correlation with investment expenditure and the effect that debt could constrain investment decision making is more effective in low growth enterprises.

Dyck and Zingales (2004) have taken financial data of listed companies in 39 countries from 1990 to 2000 as a sample and compared and analyzed transnational control gains. They found that the more concentration of equity and control of resources controlling shareholders have, the more possibility of making inefficient investment decisions that are beneficial to owners' private gains it is. As a result, they would increase their own private earnings and excessive investment behaviors would be produced as well.

\subsection{Literature Overview of Chinese Research}

Wang Luping and Mao Weiping (2010) have taken financial data of 300 manufacturing listed companies from 1999 to 2005 as a sample and researched into the relationship among investment opportunity, financial leverage and investment behaviors of enterprises. The results have shown that financial leverage has effects on investment decisions of enterprises indeed. The effects may be restraining excessive investment or leading to insufficient investment. The negative correlation of companies in high growth between financial leverage and investment expenditure is weaker than those in low growth.

On the basis of special regulations in China, Wang Jianfeng (2011) have considered conflicts of interests between controlling shareholders and small ones and have taken financial data of listed companies from 2005 to 2009 as a sample. The results have shown that aiming to domestic listed companies, the governance of debt financing is still effective under the special background of equity system in China and it is more effective against companies in low growth. Moreover, for state-owned listed companies, the inhibitory effect of financial leverage to enterprise investment behaviors is weaker for non-state-owned listed ones.

Huang Jun and Huang Ni (2012) have used the Richardson's investment model to carry out a research about real estate listed companies in China from 2006 to 2010 and have drawn a conclusion that the phenomenon of excessive investment is common because of the existence of free cash flow in our domestic real property market. Overall, debt financing could have inhibitory effect on excessive investment of real estate industries.

Zeng Chunhua and Yang Xingquan (2012) have tested that there has been excessive investment in Chinese listed companies and under pluralist engagement, debt financing makes an impact on excessive investment under multiple regression. The findings have indicated that financial leverage has greatly negative correlation with investment expenditure and then has a positive impact on company performance.

Chen Yan, Zheng Yahui and Qin Yan (2016) have found that the higher the level of operating debt is, the lower the level of new investment expenditure and the degree of inefficient investment are. The level of operating debt has positive correlation with enterprises' investment efficiency. On the contrary, when financial debt is increasing, new investment expenditure of companies is also soaring and the degree of inefficient investment is higher as well.

\subsection{Research Hypothesis}

Based on the agency problem between shareholders and managers, Jensen(1976) proposed: business managers were prone to expand the company size in their own interests, which was easy to cause over investment. However, the investment decision was constrained by the cash flow. And debt financing, debt service and hard constraints restrained the free cash flow held by management so that these can restrain the over investment. Based on the conflict between shareholders and creditors, Myers(1977) proposed that overmuch debt would cause the equality earning carved up by the great mass of creditors which made shareholders lack of motivation in project whose NPV was equal to 0 or less than interest expense. Thus under investment happened. Ownership structure of listed company in China had the attribute of equity concentration. When enterprises were facing financial crisis, the strong shareholders would provide financial support so did government holding companies. In addition, strong shareholders had similar investment tendency gained self controlled equity income. Therefore, in the condition of concentration of shares, strong shareholders, on the one hand, were prone to outbound investment, on the other hand companies had extensive sources 
of fund which weakened restriction of financial leverages to over investment. Thus, this paper proposed hypothesis as follow:

H1: financial leverage restricts efficient investment.

H1a: financial leverage restricts over investment.

H1b: financial leverage promotes under investment.

H2: equity concentration restricts efficient investment.

H2a: equity concentration restricts over investment.

$\mathrm{H} 2 \mathrm{~b}$ : equity concentration promotes under investment.

\section{Method}

\subsection{Sample Selection and Data Sources}

This paper chose the financial data of A-share listed companies on Shanghai and Shenzhen stock exchange from 2013 to 2016, analyzing the data in the model between 2014 and 2015. As the variable lags for one year, this paper chose all the A-share companies on Shanghai and Shenzhen stock exchange listed before Feb 12013 as the samples, and fitter them by following rules:(1) Weed out ST, *ST and PT companies.(2) Weed out finance and insurance companies.(3) Weed out data missing companies. Then winsorize the extreme value, and finally get (blank) samples. All the financial data are from the database of "GuoTai'an" and the analyses are finished by STATA 12.0.

\subsection{Measurement Criteria for Inefficient Investment}

According to the survey of Richardson (2006) and Qingquan Ren (2007), this paper builds an estimation model of investment level to measure the inefficient investment behaviors. And that's the flow:

(1) Use the model (1) to do regression analysis on the samples then output the excepted investment spending in $t$ year.

(2) Regard unexpected investment spending (residual series) as inefficient investment in t year calculated by subtracting actual investment spending from expected investment spending. If the residual is positive, this paper assumes that there is over investment in the company. Else if the residual is negative, there is under investment in the company.

$$
\text { Inv }_{t}=a_{0}+a_{1} \text { Growth }+a_{2} \text { Sale }+a_{3} C F+a_{4} \text { Size }+a_{5} I n v_{t-1}+\sum y e a r+\sum \text { Industry }+\varepsilon
$$

In the equation, Inv represents the total investment spending of the company which equals to the change of fixed assets in $t$ year divided by the change in $t-1$ year. And the fixed assets include fixed assets, engineering materials and construction in progress. Then Growth is expressed by enterprise revenue growth rate. Next, the value of Sales is equal to income devided fixed assets. And $C F$ represents cash flow, Size is expressed by the natural logarithm of total assets. Industry is on classfication by China Securities Regulatory Commission classification standards.

\subsection{Model Building for the Relationship between Ownership Concentration, Financial Leverage and Inefficient Investment}

According to the survey of Wang (2011), this paper builds a model (2.2) to test the relationship among ownership concentration, debt financing and inefficient investment, and the model is described as follow:

NonInv $=$

$$
a_{0}+a_{1} \text { Debt }+a_{2} S h r 1+a_{3} \text { Debt } * S h r 1+a_{4} \text { Growth }+a_{5} \text { Sale }+a_{6} C F+\sum y e a r+\sum \text { Industry }+\varepsilon
$$

In this equation, NonInv represents the efficient investment, included over investment and under investment. The difinitions of variable are as follow table 1:

\begin{tabular}{|c|c|c|c|}
\hline & Variable & Signal & Definition \\
\hline \multirow[t]{2}{*}{$\begin{array}{l}\text { explained } \\
\text { variable }\end{array}$} & Over Investment & OverInv & $\begin{array}{l}\text { The amount of over investment in } t \text { year represented by the positive } \\
\text { residual in model(1) }\end{array}$ \\
\hline & Under Investment & UnderInv & $\begin{array}{l}\text { The amount of under investment represented by the absolute of negative } \\
\text { residual in model(1) }\end{array}$ \\
\hline \multirow{2}{*}{$\begin{array}{l}\text { explanatory } \\
\text { variable }\end{array}$} & Debt financing & Debt & Total debt in $t-1$ year / total assets in $t-1$ year \\
\hline & $\begin{array}{l}\text { ownership } \\
\text { concentration }\end{array}$ & Shr1 & Shareholding ratio of the largest shareholder \\
\hline Control Variable & $\begin{array}{l}\text { Growth } \\
\text { Production capacity } \\
\text { Cash flow }\end{array}$ & $\begin{array}{l}\text { Grwoth } \\
\text { Sales } \\
\quad \text { CF }\end{array}$ & $\begin{array}{l}\text { Income growth rate in } t-1 \text { year } \\
\text { Main business income in } t-1 \text { year } / \text { fixed assets in } t-1 \text { year } \\
\text { Net cash in } t-1 \text { year / total assets in } t-1 \text { year }\end{array}$ \\
\hline
\end{tabular}

Table 1. Variables defined table 


\section{Results}

This paper uses two analysis include the panel data and the cross-section data. To measure the inefficient investment precisely in model (1), we consider the data as panel data. Then, we classify the result in model (1) to two groups: Under investment and Over investment. Finally, do the model (2) in two groups respectively.

\subsection{Choose of the Model}

The collated data is first substituted into model (1). Because of the panel data, there are three models for us to choose: Mixed effect model, fixed effect model and Random effect model, respectively. See Table 3 for details.

After calculating the VIF value of mixed effect model, we find that there is no problem of multiple collinearity. See Table 2 for details.

Table 2. VIF inspection between variables

\begin{tabular}{lll}
\hline & VIF & $1 / \mathrm{VIF}$ \\
\hline Growth & 1.13 & .881731 \\
Inv $_{\mathrm{t}-1}$ & 1.12 & .892464 \\
Sale & 1.03 & .967464 \\
$\mathrm{CF}$ & 1.01 & .987762 \\
Size & 1.01 & .994249 \\
\hline Mean VIF & 1.06 & \\
\hline
\end{tabular}

In table 2, there is no variables more than 10. In a statistical sense, we can say that there is no problem of multiple collinearity.

Table 3. Three effects result of model (1)

\begin{tabular}{llll}
\hline & OLS & $\mathrm{Re}$ & $\mathrm{Fe}$ \\
\hline Growth & .039 & .039 & $.058^{*}$ \\
Sale & .000 & -.000 & $-.019 * * *$ \\
$\mathrm{CF}$ & $-.915 * * *$ & $-.975 * * *$ & $-.920 * * *$ \\
Size & $-.069 * * *$ & $-.072 * * *$ & $-.395 * * *$ \\
Inv $_{\mathrm{t}-1}$ & $.146 * * *$ & $.098^{* * *}$ & $-.626 * * *$ \\
${ }_{\text {cons }}$ & $1.844 * * *$ & $1.946 * * *$ & $9.485 * * *$ \\
\hline \multicolumn{3}{r}{ (Legend:*p<.1;**p<.05;***p<.01) }
\end{tabular}

By observing Table 3, we find that the significance of the explanatory variables and the explained variable in the fixed effect model is the highest among three effects. As a result, we choose the fixed effect model to fit the equation and the residuals.

\subsection{Deal with data}

\subsubsection{Descriptive Statistics}

The whole sample is grouped according to the result of Equation (1). Do the descriptive statistical analysis, respectively. The results are shown in Table 4

Table 4. All sample descriptive statistics

\begin{tabular}{|c|c|c|c|c|c|}
\hline \multicolumn{6}{|c|}{ Over Investment } \\
\hline & Mean & Std. Dev. & Min & Max & Obs \\
\hline OverInv & .7244 & .4050 & .0004 & 2.1654 & 3565 \\
\hline Debt & .4446 & .2138 & .0525 & .9268 & 3565 \\
\hline Shr1 & .352 & .1519 & .0879 & .7525 & 3565 \\
\hline \multicolumn{6}{|c|}{ Under Investment } \\
\hline & Mean & Std. Dev. & Min & $\operatorname{Max}$ & Obs \\
\hline UnderInv & .744562 & .9317 & .0007 & 4.4613 & 1029 \\
\hline Debt & .4289 & .2168 & .0525 & .9268 & 1029 \\
\hline Shr1 & .3529 & .1451 & .0879 & .7525 & 1029 \\
\hline
\end{tabular}

By observing a total of 4594 sample data from 2297 companies in 2 years, 1029 samples were under-invested, accounting for $22.4 \%$ of the total sample; 3565 samples were over-invested, accounting for $77.6 \%$ of the total sample. Indicating that the two years between 2014 and 2015, Chinese A-share listed companies exist the problems of over investment.

\subsubsection{The Influence of Ownership Concentration, Financial Leverage on Inefficient Investment}

Using OLS model to analyze the impact of equity concentration and financial leverage on inefficient investment. See Table 5 for details. 
After calculating the VIF value, we find that there is no problem of multiple collinearity. See Table 6 for details.

Table 5. the impact of equity concentration, financial leverage on inefficient investment

\begin{tabular}{lll}
\hline & UnderInv & OverInv \\
\hline Debt & $.055^{*}$ & $-.010^{* * * *}$ \\
Shr1 & $.060^{*}$ & $-.004^{*}$ \\
Debt*Shr1 & .005 & $.008 * * *$ \\
Growth & $.286^{* * *}$ & 0 \\
Sale & $.225^{* * *}$ & $-.308^{* * * *}$ \\
CF & $-.034 *$ & $-.059 * * * *$ \\
Size & .011 & $-.477 * * *$ \\
cons & $.687 * * *$ & $.499 * * *$ \\
Year & Control & Control \\
Industry & Control & Control \\
$\mathrm{R}^{2}$ & .254 & .774 \\
\hline
\end{tabular}

(Legend : $* \mathrm{p}<.1 ; * \mathrm{p}<.05 ; * * * \mathrm{p}<.01$ )

Table 6. VIF inspection between variables

\begin{tabular}{lll}
\hline & VIF & 1/VIF \\
\hline Debt & 1.61 & .6217 \\
Shr1 & 1.61 & .6211 \\
Debt*Shr1 & 1.00 & .9978 \\
Growth & 1.04 & .9657 \\
Sale & 1.05 & .9545 \\
CF & 1.01 & .9878 \\
Size & 1.02 & .9820 \\
\hline Mean VIF & 1.19 & \\
\hline
\end{tabular}

From the regression results in Table 5, we found that the regression coefficient of financial leverage and under-investment is significantly positive at the significance level of $10 \%$. The regression coefficient of financial leverage and over-investment is significantly negative at the $1 \%$ significance level. This indicates that with the increase in corporate debt financing, corporate over-investment and under-investment have been suppressed and promoted, respectively. That is, financial leverage can effectively restrain the enterprise inefficient investment behavior. This assumes that H1 is validated. Besides, the result of H1a is the same with the study of He Yuan, Bai Ying (2007).

The regression coefficient of equity concentration and under-investment is significantly positive at the significance level of $10 \%$. The regression coefficient of equity concentration and overinvestment is significantly negative at the $10 \%$ significance level. This indicates that with the increase in equity concentration, corporate overinvestment and underinvestment have been suppressed and promoted, respectively. That is, the concentration of equity can effectively restrain the enterprise inefficient investment behavior. This assumes that $\mathrm{H} 2$ is validated.

It is worth noting that when explanatory variable (financial leverage, equity concentration mutual) affect the explained variable (over-investment), the regression coefficient is significantly positive at the $1 \%$ significance level. It seems indicates that the concentration of equity can undermine the inhibitory effect of high financial leverage on over-investment to some extent.

In table 6, there is no variables more than 10. In a statistical sense, we can say that there is no problem of multiple collinearity.

\section{Conclusion}

With the results of 2297 firms that being classified and analyzed from 2014 to 2015 in china's A-share market, we find the over-investment and under-investment by combine the inner mechanism of inefficient investment. Besides, we investigate the effects that ownership concentration, financial leverage impact on the inefficient investment behavior. Research shows that most Chinese A-share market enterprises have over-investment phenomenon. Increasing equity concentration or financial leverage can effectively curb inefficient investment in Chinese listed companies.

According to empirical evidence in China's A-share market. In the short term, changing the financial leverage can quickly curb the management of the inefficient investment behavior. But from a long-term perspective, high financial leverage will increase the pressure on the business. Therefore, changing the ownership structure, increasing the proportion of large shareholders have become an effective way to solve inefficient investment.

\section{Acknowledgments and Insufficient}

Investment behavior is associated with lots of factors. We tested two factors that may affect the inefficient Investment. 
Although there is relationship between Ownership concentration and the inefficient investment in China's A-share market. We can not neglect the agent problem between manager and shareholders even though they are high ownership concentration. In reality, budget soft constraints and insider control are influencing the investment behavior more universal. Thus, we will consider these factors in the next study.

Reasonable quantification has always been a difficult point for empirical research. Firstly, in model (1), the residuals are measured by the equation to resolve the inefficient investment behavior. But this assumption is that the fitting straight line is a valid investment. And the actual tend to be biased. To be more, this paper uses Shr1 to measure equity concentration. But actually the firm may have a number of closely major shareholders controlling the firm. From this point of view, it seems more accurate to choose Shr1, Shr5, Shr10 to measure the equity concentration. Finally, China's market is accompanied by state-owned holdings. We do not consider it for the reason that there is a lot difference between China and Western countries in property rights. But for the rigorous of academic, state-owned holdings is a crucial aspect of Investment behavior.

\section{References}

Aivazian, V. A., Ge, Y., \& Qiu, J. (2005). The impact of leverage on firm investment: Canadian evidence. Journal of Corporate Finance, 11(1-2), 277-291. https://doi.org/10.1016/S0929-1199(03)00062-2

Chen, Y., Zheng, Y. H., \& Qin, Y. (2016). Debt Financing, Capital Cost and Efficiency of Corporate Investment: An Empirical Analysis Based on Debt Heterogeneity. Review of Economy and Management, (4), 79-86. https://doi.org/10.13962/j.cnki.37-1486/f.2016.04.010

Claessens, S., Djankov, S., \& Lang, L. H. P. (2000). The separation of ownership and control in East Asian corporations. Journal of Financial Economics, 58(1-2), 81-112. https://doi.org/10.1016/S0304-405X(00)00067-2

Dyck, A., \& Zingales, L. (2004). Private benefits of control: an international comparison. The Journal of Finance, 59(2), 537-600. https://doi.org/10.2139/ssrn.296107

Fang, H. X., \& Jin, Y. N. (2013). Corporate Governance, Internal Control and Inefficient Investment: Theoretical Analysis and Empirical Evidence. Accounting Research, (7), 63-69. https://doi.org/10.3969/j.issn.1003-2886.2013.07.009

He, Y., Bai, Y., \& Wen, Q. Q. (2007). Debt financing, control of large shareholders and over - investment behavior of enterprises. Systems engineering, 25(3), 61-66. https://doi.org/10.3969/j.issn.1001-4098.2007.03.010

Huang, J., \& Huang, N. (2012). Over-investment, Debt Structure and Governance Effect - Empirical Evidence from Chinese Real Estate Listed Companies. Accounting Research, (9), 67-72. https://doi.org/10.3969/j.issn.1003-2886.2012.09.009

Huang, R., Marquardt, C. A., \& Zhang, B. (2014). Why do managers avoid EPS dilution? Evidence from debt-equity choice. Review of Accounting Studies, 19(2), 877-912. https://doi.org/10.1007/s11142-013-9266-3

Michael C. J. (1986). Agency Costs of Free Cash Flow, Corporate Finance, and Takeovers. The American Economics Review, 76(2), 323-329.

Rahman, D. M. (2016). Investor sentiment, executive compensation, and investment - some international evidence: a pitch. Journal of Accounting \& Management Information Systems, 15.

Stulz, R. (1990). Managerial discretion and optimal financing policies. Journal of Financial Economics, 26(1), 3-27. https://doi.org/10.1016/0304-405X(90)90011-N

Wang, J. F. (2011). Ownership structure, financial leverage and corporate investment behavior. Accounting Monthly, (6), $38-41$.

Xin, Q. Q., Lin, B., \& Wang, Y. C. (2007). Government control, manager pay and capital investment. Economic Research, (8), 110-122.

Zeng, C. H., \& Yang, X. Q. (2012). Diversification, financial leverage and over-investment. Audit \& Economy Research, 27(6), 84-92. https://doi.org/10.3969/j.issn.1004-4833.2012.06.010

\section{Copyrights}

Copyright for this article is retained by the author(s), with first publication rights granted to the journal.

This is an open-access article distributed under the terms and conditions of the Creative Commons Attribution license which permits unrestricted use, distribution, and reproduction in any medium, provided the original work is properly cited. 